\title{
UJI ORGANOLEPTIK FORMULASI FORTIFIKASI BEKATUL DALAM PEMBUATAN BUBUR INSTAN BERAS PANDANWANGI
}

\author{
Disusun oleh : \\ Riza Trihaditia **) \\ De Trisni Khoerunnisa Puspitasari*)
}

\begin{abstract}
Abstrak
Bekatul merupakan hasil limbah dari padi yang memiliki kandungan gizi yang sangat tinggi dan baik untuk kesehatan tubuh seperti aktivitas antioksidan, aktivitas kemopreventif kanker, aktivitas hipokolestrolemik dan lain-lain. Namun biasanya, bekatul hanya dimanfaatkan untuk pakan ternak saja karena rasa dan bau khas bekatul yang tidak disukai. Dengan aroma khas pandan dalam beras Pandanwangi diharapkan dapat menyamarkan bekatul dari bau tengik. Penelitian ini bertujuan untuk mengetahui pengaruh mutu organoleptik serta respon panelis pada fortifikasi bekatul pada pembuatan bubur instan beras Pandanwangi sebagai diversifikasi pangan. Data diolah menggunakan metode RSM (Response Surface Method) yang melibatkan 30 orang panelis biasa dan 1 orang panelis ahli dengan parameter yang diujikan yaitu meliputi warna, aroma, tekstur, dan rasa. Masing-masing panelis diberikan 5 sampel yang berbeda pada setiap formulasinya yaitu F1 (beras Pandanwangi 100\%: Bekatul 10\%), F2 ( beras Pandanwangi 100\%: Bekatul 20\%), F3 (beras Pandanwangi 100\%: Bekatul 30\%), F4 (beras Pandanwangi 100\%: Bekatul 40\%), dan F5 (beras Pandanwangi 100\%: Bekatul 50\%). Sedangkan untuk keseluruhan dari parameter warna, aroma, tekstur, dan rasa yang paling diminati yaitu pada sampel (beras Pandanwangi 100\%: Bekatul 50\%) dengan nilai optimasi masing-masing 3, 3, 1, dan 3.
\end{abstract}

Kata Kunci: Bekatul, Beras Pandanwangi, Bubur Instan, Fortifikasi.

\begin{abstract}
Rice bran is a waste product from rice which has a very bigh nutrient content and is good for body bealth such as antioxidant activity, cancer chemopreventive activity, hypochestrolemic activity and others. However, in its life bran is only used for animal feed because of the distinctive taste and smell of rice bran. The distinctive aroma of pandanus in Pandanwangi rice, it is expected to disguise bran from a rancid smell. The aim of this studies was to determine the effect of organoleptic quality and the response of panelists of bran fortification in the manufacture of Pandanwangi rice instant porridge as food diversification. The data is processed using the RSM (Response Surface Method) this method which involves 30 ordinary panelists and 1 expert panelist with the parameters being tested which include color, aroma, texture, and taste. Each panelist was given 5 different samples on each formulation namely F1 (100\% Pandanwangi rice: 10\% bran), F2 (100\% Pandanwangi rice: $20 \%$ bran), F3 (100\% Pandanwangi rice: $30 \%$ bran), F4 (100\% Pandanwangi rice: $40 \%$ bran), and F5 (100\% Pandanwangi rice: 50\% bran). Whereas for the most desirable color, aroma, texture and taste parameters, namely sample (100\% Pandanwangi rice: 50\% bran) with 3, 3, 1, and 3 optimization values respectively.
\end{abstract}

Keywords: Bran, Pandanwangi Rice, Instant Porridge, Fortification.

*) Alumni Fakultas Sains Terapan UNSUR

**) Dosen Fakultas Sains Terapan UNSUR

$\begin{array}{lrr}\text { UJI ORGANOLEPTIK } & \text { FORMULASI } & \text { RIZA TRIHADITIA } \\ \text { FORTIFIKASI BEKATUL } & \text { DALAM } & \text { DE TRISNI KHOERUNNISA PUSPITASARI } \\ \text { PEMBUATAN BUBUR INSTAN } & & \\ \text { BERAS PANDANWANGI } & & \end{array}$




\section{PENDAHULUAN}

Beras merupakan makanan pokok yang dikonsumsi oleh sebagian besar penduduk Indonesia khususnya daerah Cianjur. Cianjur merupakan daerah yang memiliki berbagai jenis beras berkualitas salah satunya yaitu beras Pandanwangi. Beras Pandanwangi adalah beras varietas lokal yang berasal dari daerah Cianjur yang memiliki keunggulan seperti rasa yang enak, pulen, beraroma khas wangi pandan dan warna beras yang putih (MP3C, 2015).

Beras Pandanwangi juga termasuk salah satu beras yang melalui proses penyosohan sehingga beras yang dihasilkan berwarna putih. Semakin tinggi derajat sosoh maka beras yang dihasilkan akan semakin putih dan bersih, namun dilihat dari kandungan gizinya justru akan semakin sedikit (Astawan dan Leomitro, 2009).

Bekatul merupakan limbah atau hasil samping dari proses penyosohan kedua setelah dilakukan penyosohan pertama. Bekatul memiliki kandungan nilai gizi yang cukup baik untuk kesehatan dan lebih besar dibandingkan dengan kandungan nilai gizi pada beras. Kandungan gizi yang terdapat dalam bekatul diantaranya serat pangan, asam lemak tidak jenuh, sterol, protein dan juga mineral (Astawan dan Febrinda, 2010). Beberapa ahli gizi menyatakan bahwa kandungan fitosterol dan serat pangan dalam bekatul bersinergi kuat dalam menurunkan kolesterol dalam darah (Astawan dan Leomitro, 2009).

Selain bekatul, dalam penggilingan padi terdapat hasil samping yang harganya lebih ekonomis dan dapat meningkatkan efisiensi penggilingan beras yaitu menir. Menir merupakan beras pecah dengan ukuran kurang dari 2/10 beras utuh (Anonim, 2005). Pada penggilingan padi diperoleh: beras sekitar $60 \%$, menir 5-8 \%, bekatul 8-12\% dan sekam. Dengan produksi gabah hampir 60 juta ton, maka produksi menir sekitar 3 4,8 juta ton, sehingga menir dapat dimanfaatkan sebagai pengolahan pangan sekaligus pengganti beras utuh. (Wariyah, 2010).

Pemanfaatan bekatul dan menir selain sebagai pakan ternak dapat berupa penggunaan kembali sebagai pangan fungsional alternatif dan merupakan bentuk dari diversifikasi pangan. Pangan fungsional yaitu pangan olahan yang mengandung satu atau lebih komponen fungsional yang mempunyai fungsi fisiologis tertentu dan terbukti tidak membahayakan dan bermanfaat bagi kesehatan (BPOM, 2005).

Meskipun bekatul memiliki kandungan gizi tinggi dan berpotensi untuk kesehatan seperti aktivitas antioksidan, aktivitas kemopreventif kanker, aktivitas hipokolesterolemik dan lain-lain (Tuarita et al., 2017). Namun, masyarakat yang mengonsumsi bekatul masih sedikit karena rasanya yang sangat tidak disukai. Oleh karena itu, perlu adanya pengolahan untuk meningkatkan minat masyarakat dalam mengkonsumsi bekatul.

Dengan bentuk diversifikasi pangan bekatul dapat digunakan sebagai bahan untuk fortifikasi pada olahan beras Pandanwangi dengan kandungan gizinya yang sedikit berkurang akibat proses penyosohan. Fortifikasi merupakan penambahan zat-zat gizi ke dalam bahan pengan sehingga dapat meningkatkan nilai gizi dan mengembalikan zat-zat gizi tertentu pada pangan tersebut (Handayani, 2016).

Salah satu olahan dari beras Pandanwangi yang dapat dikonsumsi oleh setiap kalangan seperti anak-anak, remaja, maupun orang tua adalah bubur. Bubur merupakan olahan pangan yang mudah dikonsumsi masyarakat karena memiliki tekstur yang lembut atau lunak sehingga mudah dicerna. Dengan penambahan bekatul pada bubur beras Pandanwangi maka akan menambahkan kandungan nilai

\section{UJI ORGANOLEPTIK FORMULASI FORTIFIKASI BEKATUL DALAM PEMBUATAN BUBUR INSTAN BERAS PANDANWANGI


gizi yang hilang. Namun, salah satu kelemahan bekatul bersifat cepat rusak dan sangat peka terhadap faktor lingkungan sehingga olahan bubur yang diberi fortifikasi bekatul akan mudah basi atau dengan masa simpan yang relatif singkat (Astawan dan Leomitro, 2009).

Oleh karena itu, diperlukan cara untuk meningkatkan ketahanan olahan bubur yang diberi fortifikasi bekatul dengan cara membuat bubur beras instan. Bubur instan merupakan makanan yang mengalami proses pengeringan sehingga mudah larut dan mudah disajikan hanya dengan menambahkan air panas serta dapat meningkatkan lama masa simpan.

Berdasarkan latar belakang tersebut, penulis membuat bubur instan beras Pandanwangi yang diberi bekatul sebagai bahan fortifikasi.

Adapun dari uraian di atas dapat ditarik rumusan masalah yaitu Bagaimana pengaruh fortifikasi bekatul terhadap mutu organoleptik bubur instan beras Pandanwangi dan bagaimana respon panelis uji organoleptik fortifikasi bekatul pada pembuatan bubur instan beras Pandanwangi sebagai diversifikasi pangan.

Sedangkan tujuan dari penelitian ini antara lain yaitu untuk Mengetahui pengaruh fortifikasi bekatul terhadap mutu organoleptik bubur instan beras Pandanwangi dan untuk mengetahui respon panelis uji organoleptik fortifikasi bekatul pada pembuatan bubur instan beras Pandanwangi sebagai diversifikasi pangan.

\section{METODE PENELITIAN}

Penelitian ini dilaksanakan dengan diawali oleh uji pendahuluan pada 29 Januari 2019, selanjutnya penelitian dilanjutkan dengan uji sesungguhnya yang dilaksanakan pada 24 April 2019 di Laboratorium Pangan Fakultas Sains Terapan Universitas Suryakancana Cianjur.
Penelitian ini termasuk ke dalam jenis penelitian eksperimental yaitu dengan data yang diperoleh menggunakan uji organoleptik untuk mengetahui penilaian mutu hedonik pada fortifikasi bekatul dalam pembuatan bubur instan dari beras Pandanwangi. Penelitian ini dimulai dari proses penyediaan bekatul dan proses pembuatan fortifikasi bekatul dalam bubur instan beras Pandanwangi hingga menguji organoleptik kepada panelis.

\section{Alat dan Bahan}

Peralatan yang digunakan untuk pembuatan fortifikasi bekatul terhadap bubur instan beras Pandanwangi adalah panci, ayakan, sendok, blender, loyang, oven, kompor, plastik aluminium foil klip, label dan alat tulis. Sedangkan peralatan yang digunakan untuk uji organoleptik adalah cup plastik, sendok plastik, thermos, dan kertas kuesioner uji organoleptik.

Bahan yang digunakan untuk pembuatan fortifikasi bekatul terhadap bubur instan beras Pandanwangi adalah bekatul dan menir Pandanwangi, serta bahan penambah yaitu air bersih. Menir Pandanwangi diperoleh dari Gasol Pertanian Orgaanik dan bekatul Pandanwangi diperoleh dari salah satu petani Pandanwangi di Cibeber- Cianjur. Selanjutnya, bahan yang digunakan untuk uji organoleptik adalah bubur instan beras Pandanwangi yang diberi tambahan bekatul sebagai fortifikasi sesuai dengan formulasi yang ditetapkan dan air panas.

\section{Proses Pembuatan}

Berdasarkan penelitian ini, proses pembuatan bubur instan beras Pandanwangi dengan fortifikasi bekatul adalah sebagai berikut:

1) Beras dicuci bersih

2) Beras dimasukkan ke dalam panci dan diberi air sampai beras terendam yaitu 1:4, 1 untuk beras dan 4 untuk air.

$\begin{array}{lrr}\text { UJI ORGANOLEPTIK } & \text { FORMULASI } & \text { RIZA TRIHADITIA } \\ \text { FORTIFIKASI B BEKATUL } & \text { DALAM } & \text { DE TRISNI KHOERUNNISA PUSPITASARI } \\ \text { PEMBUATAN BUBUR INSTAN } & & \\ \text { BERAS PANDANWANGI } & & \end{array}$


3) Tanak dalam api sedang, bubur diaduk sampai matang dan didiamkan hingga dingin.

4) Bubur diblending sampai tekstur bubur agak halus.

5) Bubur yang telah diblender dimasukkan kedalam loyang dengan ketebalan bubur agak tipis.

6) Loyang dimasukkan ke dalam oven dengan pengaturan api $80^{\circ} \mathrm{C}$. Tunggu sampai bubur instan matang selama 5 jam.

7) Bubur instan ditumbuk agar menjadi serpihan kecil.

Proses pembuatan fortifikasi bekatul dalam bubur instan beras Pandanwangi disajikan pada gambar 1 . diagram alir dibawah ini

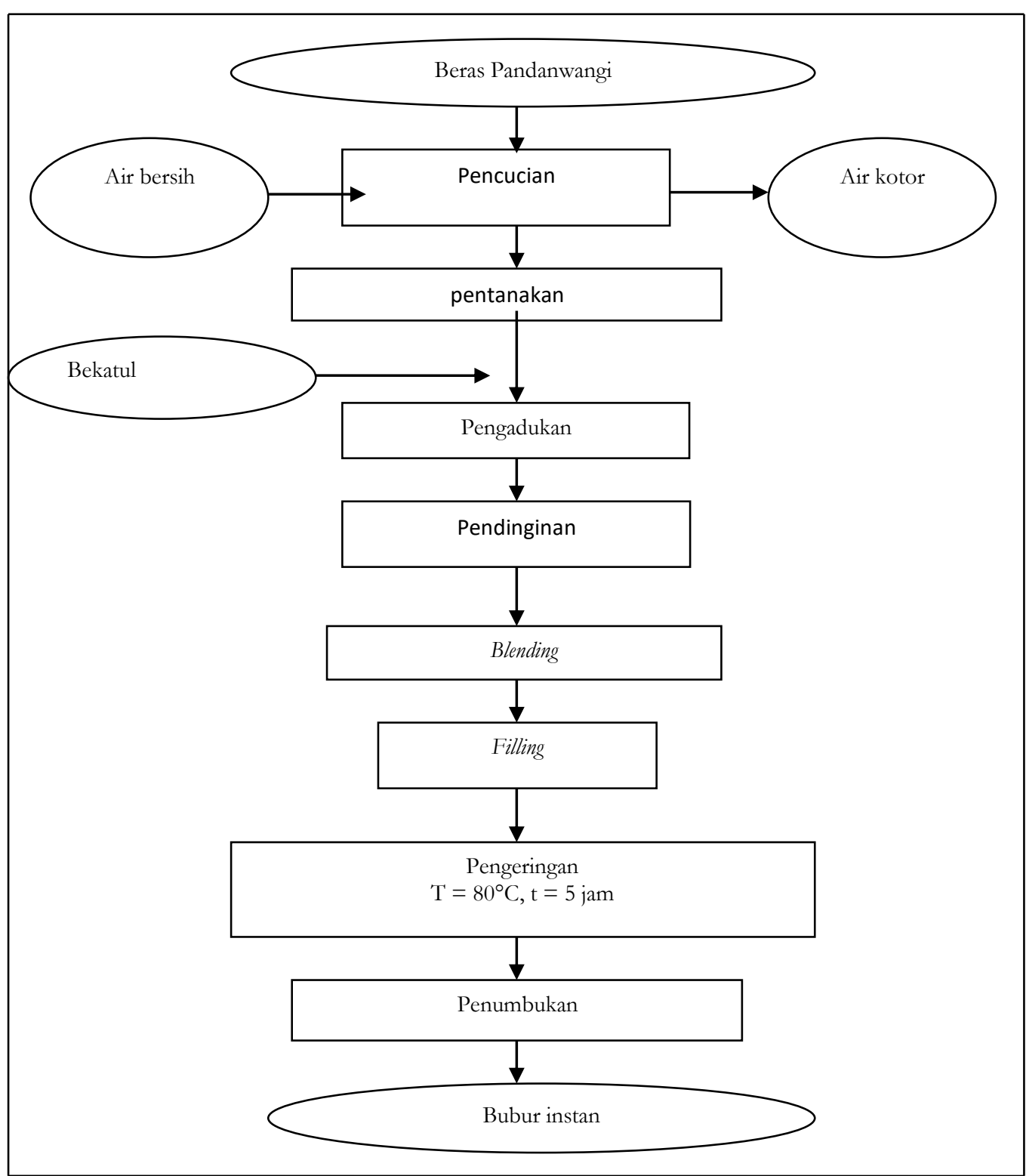

Gambar 1. Diagram alir proses pembuatan. 


\section{Rancangan Percobaan}

Dalam penelitian ini terdapat lima perlakuan, diantaranya:

1) Formula 1 (F1): beras Pandanwangi 100\%: Bekatul 10\%

2) Formula 2 (F2): beras Pandanwangi 100\%: Bekatul 20\%

3) Formula 3 (F3): beras Pandanwangi 100\%: Bekatul 30\%

4) Formula 4 (F4): beras Pandanwangi 100\%: Bekatul 40\%

5) Formula 5 (F5): beras Pandanwangi 100\%: Bekatul 50\%

Data diperoleh menggunakan Uji organoleptik yang dilakukan yaitu uji mutu hedonik oleh 30 orang panelis biasa atau tidak ahli dan 1 orang panelis ahli. Uji ini dilakukan untuk mengetahui penilaian panelis terhadap produk fortifikasi bekatul pada bubur instan Pandanwangi yang telah dibuat. Uji mutu hedonik dilakukan terhadap warna, aroma, rasa, tekstur, dan keseluruhan produk tersebut.

Data uji organoleptik yang telah didapat kemudian diolah menggunakan minitab16, selanjutnya akan diketahui perlakuan yang optimal dengan menggunakan RSM (Response Surface Method). Metode RSM atau Respon Permukaan Metodologi merupakan kumpulan teknik matematik dan statistik yang digunakan untuk modeling dan analisis permasalahn pada respon yang dipengaruhi oleh beberapa variabel dan bertujuan memperoleh optimasi respon
(Montgomery, 2001 dalam Aritonang, 2014).

Penggunaan metode ini yaitu berfungsi untuk mengembangkan, meningkatkan, dan mengoptimasi bagaimana proses penentuan formulasi optimum. Penerapannya ini sangat penting terutama di bidang rancangan, pengembangan dan perumusan produk baru, serta pada peningkatan rancangan produk yang sudah ada (Trihaditia, 2015).

\section{HASIL DAN PEMBAHASAN}

Hasil dari penelitian ini akan menjelaskan mengenai pembahasan dan penentuan sampel terbaik dari bekatul yang digunakan sebagai fortifikasi pada pembuatan bubur instan beras Pandanwangi sebagai makanan fungsional yang dinilai dari parameter warna, aroma, tekstur dan rasa serta keseluruhan produk.

\section{A. Warna}

Warna merupakan faktor pertama yang mudah untuk diamati dalam mutu bahan pangan. Penilaian kualitas sensori pada produk pangan bisa dilihat dari bentuk, ukuran, kejernihan, warna, dan sifat pemukaan seperti kasar-halus, suram, mengkilap, homogeny-heterogen, dan bentuk lainnya (Sarbini et al., 2009).

Data olahan yang diperoleh dari hasil uji organoleptik didapatkan hasil pada gambar 2 .

$\begin{array}{lrrr}\text { UJI ORGANOLEPTIK } & \text { FORMULASI } & \text { RIZA TRIHADITIA } \\ \text { FORTIFIKASI G BEKATUL } & \text { DALAM } & \text { DE TRISNI KHOERUNNISA PUSPITASARI } \\ \text { PEMBUATAN BUBUR INSTAN } & & \\ \text { BERAS PANDANWANGI } & & \end{array}$




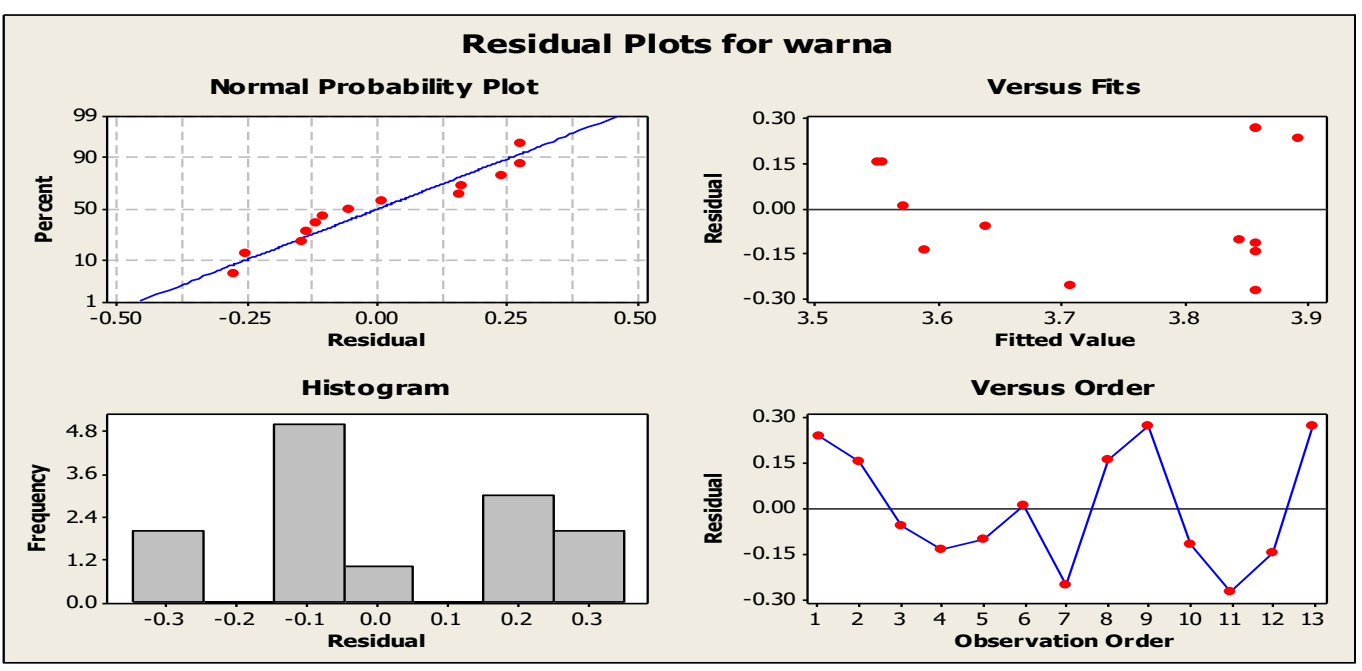

Gambar 2. Grafik Perhitungan ANOVA dari Parameter Warna.

Dari gambar 2. dapat dilihat bahwa titik-titik data yang menyebar mendekati dengan garis normal probability, sehingga dapat dikatakan bahwa data untuk respon warna tersebut menyebar secara normal atau merata yang berarti mempunyai normal probability yang baik. Untuk itu, dengan data-data yang dihasilkan tersebut dapat dilakukan perhitungan selanjutnya yaitu menghitung nilai optimasi dari parameter warna dengan perhitungan di bawah:

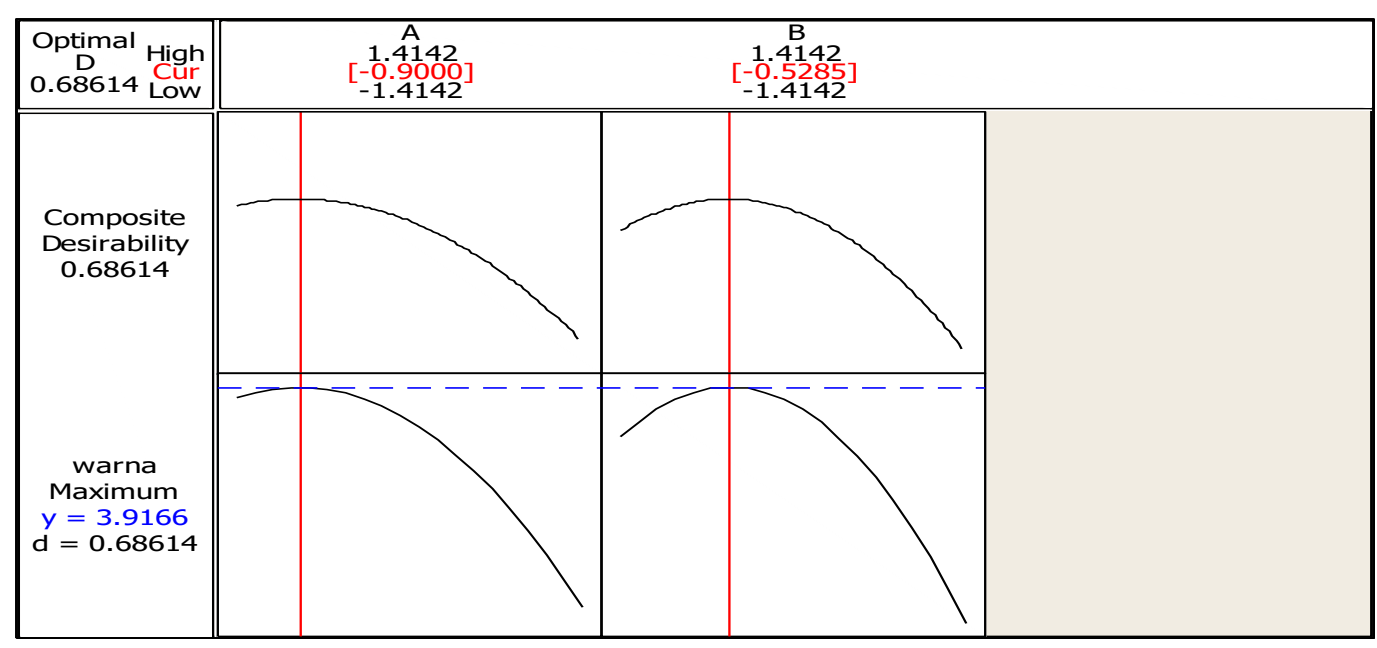

Gambar 3. Nilai Optimasi Dari Parameter Warna.

Dari gambar 3. di atas, dapat dilihat bahwa nilai optimal dari parameter warna adalah 3.9166, dimana akan membentuk suatu parabola yang terbuka ke bawah yang mencirikan bahwa nilai parameter warna tersebut mempunyai nilai optimal. Selanjutnya adalah penentuan daerah optimasi digunakan grafik secara contour dan surface, maka akan dihasilkan perhitungan pada gambar 4 .

\section{UJI ORGANOLEPTIK FORMULASI FORTIFIKASI BEKATUL DALAM PEMBUATAN BUBUR INSTAN BERAS PANDANWANGI}

RIZA TRIHADITIA DE TRISNI KHOERUNNISA PUSPITASARI 


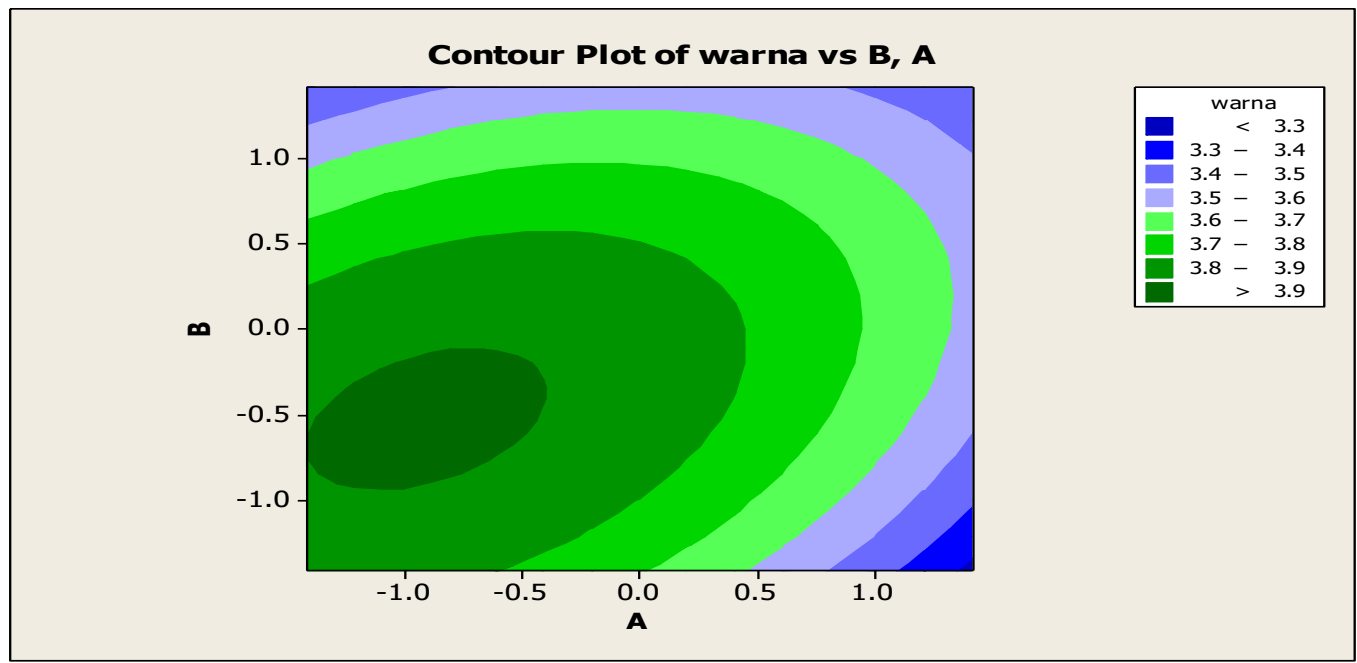

Gambar 4. Grafik Contour Plot Wilayah Optimasi dari Warna.

Grafik contour plot pada gambar 4. menggambarkan bagaimana kombinasi antar komponen saling mempengaruhi nilai respon untuk parameter warna pada bubur instan beras Pandanwangi dengan fortifikasi bekatul. Warna-warna yang berbeda pada grafik tersebut menunjukan nilai respon dari warna masing-masing formula. Bentuk permukaan dari hubungan interaksi antar komponen tersebut dapat dilihat secara jelas pada grafik tiga dimensi yaitu pada grafik surface wilayah optimasi yang ditunjukanpada gambar 5 .

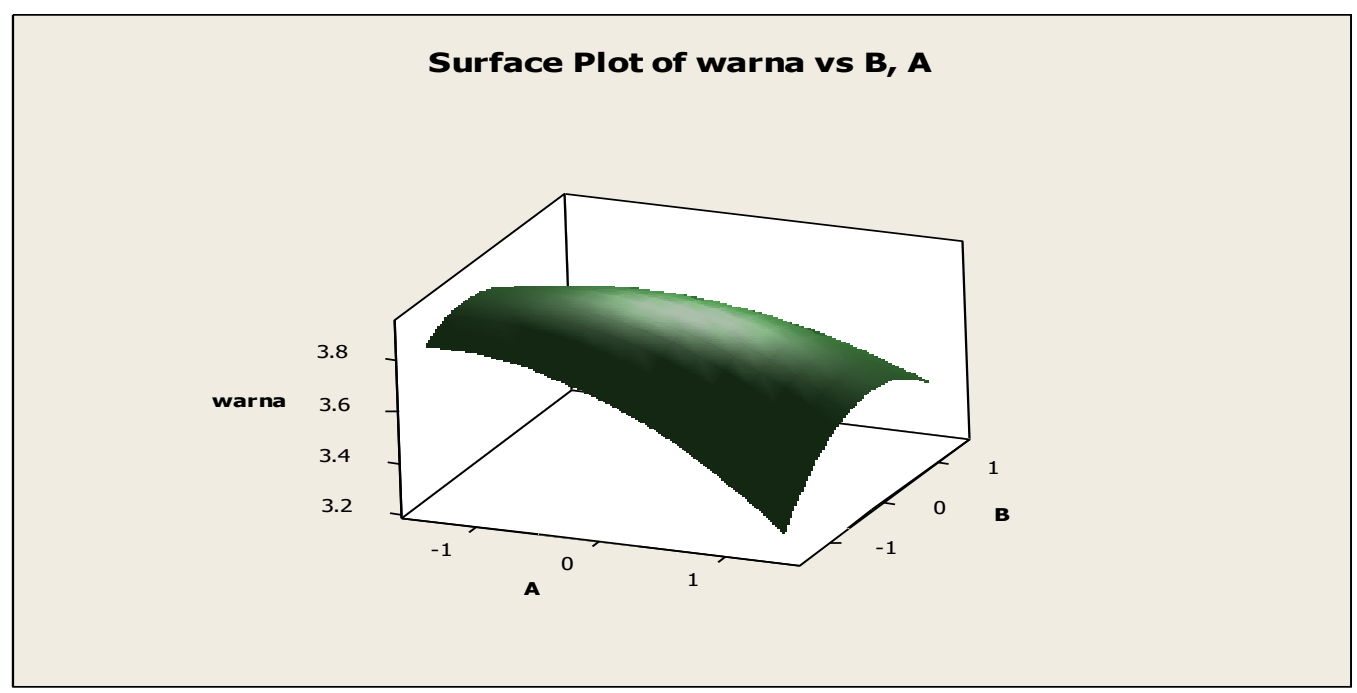

Gambar 5. Grafik Surface Wilayah Optimasi dari Warna.

Dari gambar-gambar diatas dapat diketahui batas-batas atau penentuan wilayah optimasi. Batasan wilayah untuk nilai optimasi warna adalah antara 3.3 -
3.9, sehingga didapatkan penentuan wilayah optimasi berdasarkan nilai ratarata sampel pada tabel 1 .

\section{UJI ORGANOLEPTIK FORMULASI \\ FORTIFIKASI BEKATUL DALAM PEMBUATAN BUBUR INSTAN BERAS PANDANWANGI}

RIZA TRIHADITIA DE TRISNI KHOERUNNISA PUSPITASARI 
Tabel 1. Wilayah Optimasi Rata-rata Warna.

\begin{tabular}{cc}
\hline Wilayah Optimasi & Rata-rata Warna \\
\hline 1 & $>3.9$ \\
2 & $3.8-3.9$ \\
3 & $3.7-3.8$ \\
4 & $3.6-3.7$ \\
5 & $3.5-3.6$ \\
6 & $3.4-3.5$ \\
7 & $3.3-3.4$ \\
8 & $<3.3$ \\
\hline
\end{tabular}

Sumber: Data primer (olahan) tahun 2019.

Untuk mendapatkan nilai optimal dari berbagai jenis sampel yang digunakan, maka nilai rata-rata dari setiap sampel dimasukkan ke dalam plot wilayah

Tabel 2. Nilai Optimasi Rata-rata Warna.

\begin{tabular}{ccc}
\hline Sampel & Rata-rata & Wilayah Optimasi \\
\hline F1 (PW 100\%: BK 10\%) & 4.13 & 1 \\
F2 (PW 100\%: BK 20\%) & 3.71 & 3 \\
F3 (PW 100\%: BK 30\%) & 3.58 & 5 \\
F4 (PW 100\%: BK 40\%) & 3.45 & 6 \\
F5 (PW 100\% : BK 50\%) & 3.74 & 3 \\
\hline
\end{tabular}

Sumber : Data primer (olahan) tahun 2019.

*Keterangan : PW (beras Pandanwangi) BK (Bekatul).

Dari tabel 2. dapat diketahui bahwa nilai terbaik untuk optimasi warna adalah sampel dengan F1 (PW 100\% : BK 10\%), dikarenakan sampel tersebut mempunyai nilai optimasi 1 dan nilai ratarata berada di wilayah dengan nilai optimasi tertinggi. Nilai tersebut diperoleh karena diduga panelis menyukai bubur beras yang memiliki warna terang (putih) dan menurut persepsi masyarakat tentang bubur adalah bahwa bubur beras umumnya berwarna putih sehingga penilaian panelis pada F1 dengan fortifikasi bekatul sebanyak 10\% atau yang paling sedikit dari formulasi lain lebih disukai.

Menurut Tetelepta dan Picauly (2015), suatu bahan makanan yang dinilai bergizi tinggi, enak dan teksturnya sangat baik tidak akan dimakan apabila memiliki warna yang tidak sedap dipandang. Pada bubur instan beras Pandanwangi dengan fortifikasi bekatul, perbedaan warna antar setiap formulasi agak dapat dibedakan, optimasi, sehingga dihasilkan nilai optimasi dari setiap sampel tersebut yang dapat diihat pada tabel 2 . karena warna bubur berwarna hampir sama yang dipengaruhi oleh campuran beras Pandanwangi yang putih dan bekatul yang berwarna kecoklatan (coklat muda). Warna coklat ini disebabkan oleh senyawa fitokimia yang dimiliki bekatul (Sarbini et al., 2009).

Perbedaan warna tersebut menunjukan bahwa penambahan bekatul sebagai fortifikasi dengan formulasi yang berbeda berpengaruh terhadap warna bubur beras instan sehingga mempengaruhi penilaian atau minat panelis. Selain itu, menurut Winarno (2004) penerimaan warna pada suatu makanan tergantung dari faktor alami, geografi dan aspek sosial masyarakat (panelis) itu sendiri. Hal itu disebabkan karena setiap manusia memiliki tingkat kesukaan yang berbeda terhadap setiap makanan yang dikonsumsinya.

\section{UJI ORGANOLEPTIK FORMULASI FORTIFIKASI BEKATUL DALAM PEMBUATAN BUBUR INSTAN BERAS PANDANWANGI}

RIZA TRIHADITIA DE TRISNI KHOERUNNISA PUSPITASARI 


\section{B. Aroma}

Aroma merupakan penilaian bau yang dilakukan oleh indra penciuman yaitu hidung. Dengan aroma yang menarik, maka akan menimbulkan selera panelis dalam mengkonsumsi bubur instan. Aroma dalam suatu produk makanan merupakan faktor yang penting dalam menentukan tingkat penerimaan konsumen pada penentuan kelezatan bahan makanan, biasanya seseorang dapat menilai lezat atau tidaknya suatu bahan makanan dari aroma yang ditimbulkan (Hadi dan Siratunnisak, 2016).

Berdasarkan uji organoleptik terhadap aroma pada bubur instan beras Pandanwangi dengan fortifikasi bekatul dapat dilihat pada data yang kemudian dibuat design penelitian. Selanjutnya, dilakukan perhitungan Central Composite Design dengan hasil grafik pada gambar 6 .

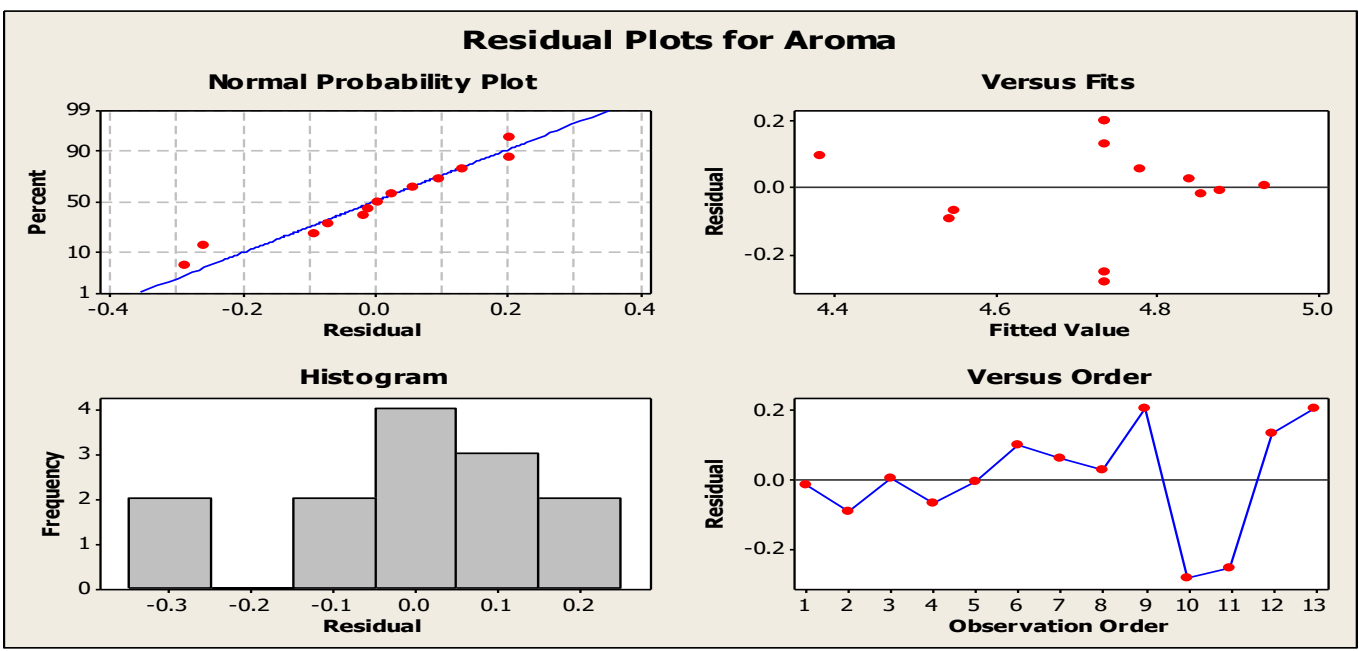

Gambar 6. Grafik Perhitungan ANOVA dari Parameter Aroma

Berdasarkan gambar 6. terlihat bahwa titik-titik data menyebar dekat dengan garis normal dan sebagian titiktitik data berada disepanjang garis normal probability, sehingga dapat dikatakan bahwa data untuk respon aroma menyebar normal. Data yang menyebar normal menunjukan adanya pemenuhan model terhadap asumsi ANOVA pada respon aroma sehingga dapat dilakukan perhitungan selanjutnya yaitu dengan menghitung nilai optimasi dari parameter aroma pada gambar 7 .

\section{UJI ORGANOLEPTIK FORMULASI FORTIFIKASI BEKATUL DALAM PEMBUATAN BUBUR INSTAN BERAS PANDANWANGI}

RIZA TRIHADITIA DE TRISNI KHOERUNNISA PUSPITASARI 


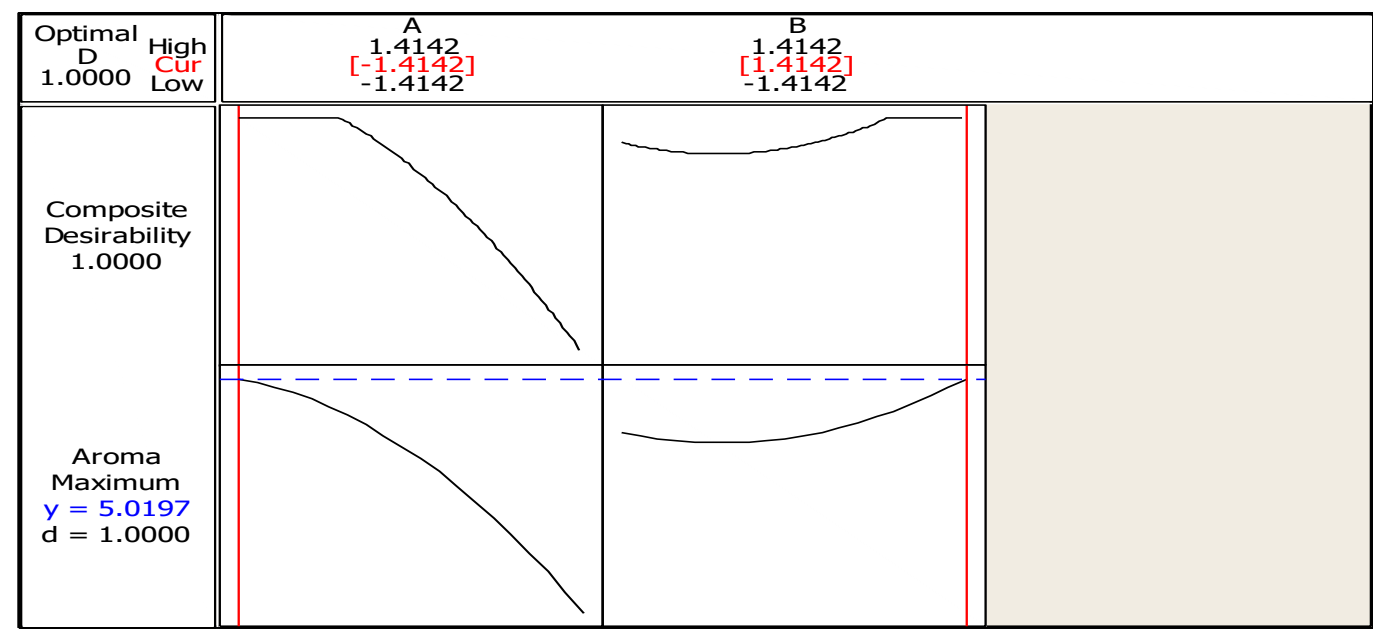

Gambar 7. Nilai Optimasi dari Parameter Aroma.

Berdasarkan gambar 7. bahwa nilai optimal dari parameter aroma yaitu 5.0197, dimana garis tersebut akan membentuk suatu parabola yang terbuka ke bawah yang mencirikan bahwa nilai respon aroma mempunyai nilai optimal.
Kemudian, untuk penentuan daerah optimasi digunakan grafik secara contour dan surface, maka akan dihasilkan perhitungan berikut:

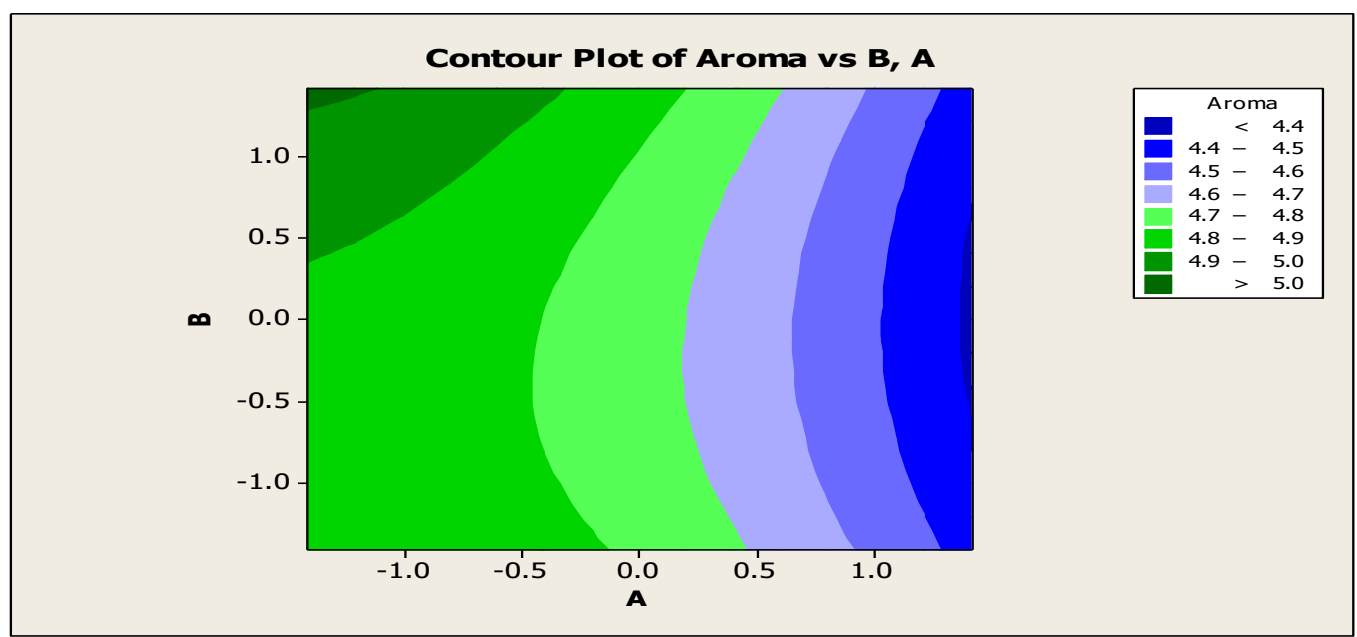

Gambar 8. Grafik Contour Plot Wilayah Optimasi dari Aroma.

Berdasarkan grafik contour plot pada gambar 8. menggambarkan bagaimana kombinasi antar komponen saling mempengaruhi nilai respon untuk parameter aroma pada bubur instan beras Pandanwangi dengan fortifikasi bekatul. Warna-warna yang berbeda pada grafik tersebut menunjukan nilai respon dari aroma masing-masing formula. Bentuk permukaan dari hubungan interaksi antar komponen tersebut dapat dilihat secara jelas pada grafik tiga dimensi yaitu pada grafik surface wilayah optimasi yang ditunjukan pada gambar 9 .

$\begin{array}{lrr}\text { UJI ORGANOLEPTIK } & \text { FORMULASI } & \text { RIZA TRIHADITIA } \\ \text { FORTIFIKASI } \quad \text { BEKATUL } & \text { DALAM } & \text { DE TRISNI KHOERUNNISA PUSPITASARI } \\ \text { PEMBUATAN BUBUR INSTAN } & & \\ \text { BERAS PANDANWANGI } & & \end{array}$




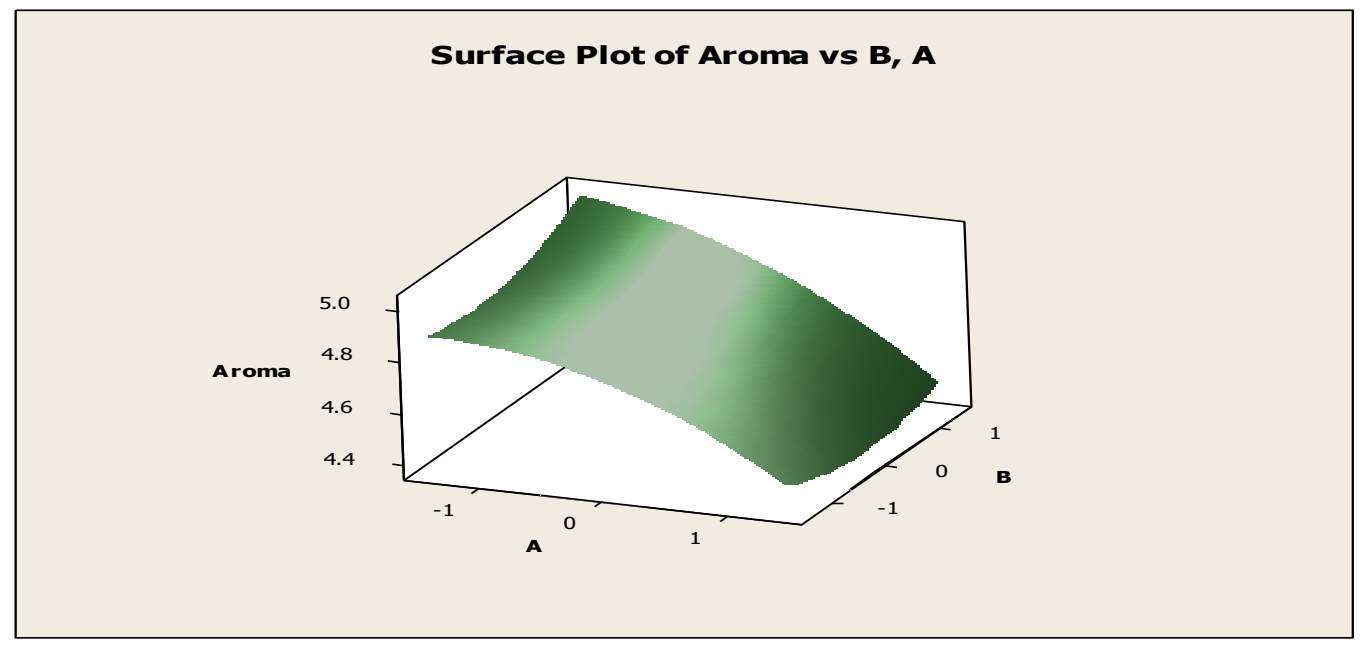

Gambar 9. Grafik Surface Wilayah Optimasi dari Aroma.

Selain itu, pada gambar 9. dapat diketahui batas-batas atau penentuan wilayah optimasi. Batasan wilayah untuk nilai optimasi aroma

Tabel 3. Wilayah Optimasi Rata-rata Aroma

\begin{tabular}{cc}
\hline Wilayah Optimasi & Rata-rata Aroma \\
\hline 1 & $>5.0$ \\
2 & $4.9-5.0$ \\
3 & $4.8-4.9$ \\
4 & $4.7-4.8$ \\
5 & $4.6-4.7$ \\
6 & $4.5-4.6$ \\
7 & $4.4-4.5$ \\
8 & $<4.4$ \\
\hline
\end{tabular}

Sumber : Data primer (olahan) tahun 2019.

Untuk memperoleh nilai optimal dari berbagai jenis sampel yang digunakan, maka nilai rata-rata dari setiap sampel dimasukkan ke dalam plot wilayah adalah antara 4.4 - 5.0, sehingga didapatkan penentuan wilayah optimasi berdasarkan nilai rata-rata sampel pada tabel 3.

Tabel 4.. Nilai Optimasi Rata-rata Aroma

\begin{tabular}{ccc}
\hline Sampel & Rata-rata & Wilayah Optimasi \\
\hline F1 (PW 100\%: BK 10\%) & 4.84 & 3 \\
F2 (PW 100\%: BK 20\%) & 4.45 & 7 \\
F3 (PW 100\%: BK 30\%) & 4.94 & 2 \\
F4 (PW 100\%: BK 40\%) & 4.48 & 7 \\
F5 (PW 100\%: BK 50\%) & 4.87 & 3 \\
\hline
\end{tabular}

Sumber : Data primer (olahan) tahun 2019.

*Keterangan : PW (beras Pandanwangi) BK (Bekatul).

optimasi, sehingga dihasilkan nilai optimasi dari setiap sampel tersebut yang dapat diihat pada tabel 4.

\begin{tabular}{lrr}
\hline UJI ORGANOLEPTIK & FORMULASI & RIZA TRIHADITIA \\
FORTIFIKASI B BEKATUL & DALAM & DE TRISNI KHOERUNNISA PUSPITASARI \\
PEMBUATAN BUBUR INSTAN & & \\
BERAS PANDANWANGI & &
\end{tabular}


Berdasarkan Tabel 4. dapat diketahui bahwa sampel terbaik untuk nilai optimasi aroma ada pada sampel F3 (PW 100\% : BK 30\%) yaitu dengan memiliki nilai optimasi 2 yang rata-rata sampelnya berada di wilayah dengan nilai optimasi 2. Dari hasil penelian berikut dapat dikatakan bahwa penilaian panelis terhadap sampel F3 (PW 100\% : BK $30 \%$ memiliki respon yang bagus meskipun tidak berada pada wilayah optimasi pertama. Hal ini disebabkan, karena aroma khas wangi pandan dari beras Pandanwangi yaitu aroma khusus yang terkandung adalah 2-asetil-1-pirolina (2AP) dan senyawa volatile seperti hidrokarbon, alkohol, ester, aldehid, keton, dan senyawa volatile lainnya (Wijaya et al., 2008). Hal ini diperkuat oleh Suhendri (2013) dalam Nurjaya dan Maulida (2018), yang menyatakan bahwa perbedaan aroma yang terdapat dalam beras Pandanwangi dengan beras yang tidak memiliki aroma khusus adalah dari kandungan alkohol (n-pentanol, 1- oktan3-ol, mentol dan estragol), aldehid dan keton ( n-pentanal, n-heptanal dan nnonanal) yang lebih tinggi. Padi beraroma ini memiliki 15 kali lebih banyak 2-asetil-1 pirolina dibandingkan padi biasa.

Aroma khas Pandanwangi tersebut dapat menutupi aroma khas dari bekatul yang memiliki aroma tengik. Dengan penambahan bekatul yang tidak terlalu banyak ataupun sedikit tersebut (posisi moderat/ sedang), diduga panelis lebih menyukai perpaduan antara aroma wangi pandan dengan aroma bekatul yang dapat menyamarkan ketengikan pada bekatul tersebut, sehingga hanya menimbulkan aroma khas dari bubur instan itu sendiri.

Aroma berhubungan dengan indera penciuman. Adanya aroma khas bekatul disebabkan oleh adanya minyak tokoferol (komponen volatil) pada bekatul (Sarbini et al., 2009). Sedangkan, aroma tengik dari bekatul berasal ketika lapisan dedak dipisah dari endosperma selama proses penggilingan, ketika sel-selnya terpisah dan lemak bekatul terhubung dengan enzim lipase yang sangat reaktif. Enzim ini keduanya menyelubungi bekatul dan menginisiasi ketengikan hidrolitik minyak biji (Ramezanzadeh et al., 1999 dalam Yunita et al., 2014).

\section{Tekstur}

Tekstur merupakan parameter yang dapat dinilai dari mengunyah atau memijat bubur instan beras Pandanwangi dengan fortifikasi bekatul apakah bubur tersebut memiliki kekentalan, keenceran, halus, ataupun kasar.

Berdasarkan uji organoleptik terhadap tekstur pada bubur instan beras Pandanwangi dengan fortifikasi bekatul dapat dilihat pada hasil data pada gambar 10.

$\begin{array}{lrr}\text { UJI ORGANOLEPTIK } & \text { FORMULASI } & \text { RIZA TRIHADITIA } \\ \text { FORTIFIKASI O BEKATUL } & \text { DALAM } & \text { DE TRISNI KHOERUNNISA PUSPITASARI } \\ \text { PEMBUATAN BUBUR INSTAN } & & \\ \text { BERAS PANDANWANGI } & & \end{array}$




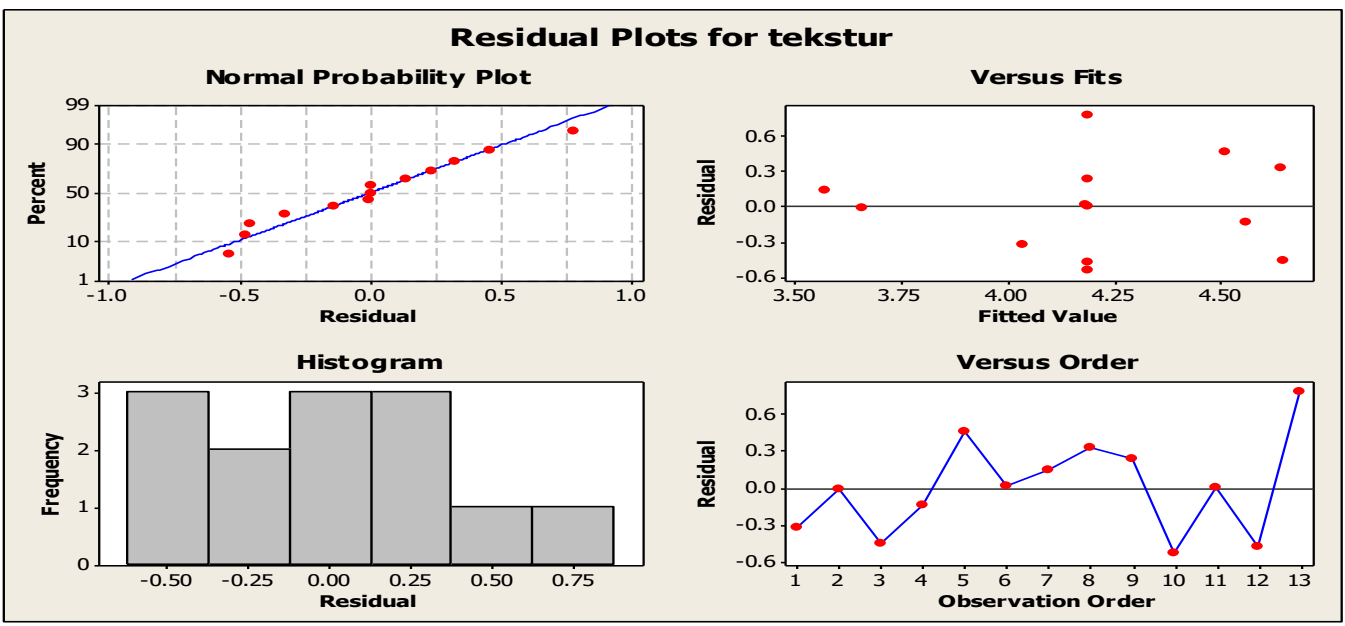

Gambar 10. Grafik Perhitungan ANOVA dari Parameter Tekstur.

Terlihat pada gambar 10. bahwa titik-titik data menyebar dekat dengan garis normal dan sebagian titik-titik data berada disepanjang garis normal probability, sehingga dapat dikatakan bahwa data untuk respon tekstur menyebar normal atau merata. Data yang menyebar normal menunjukan adanya pemenuhan model terhadap asumsi ANOVA pada respon tekstur, sehingga dapat dilakukan perhitungan selanjutnya yaitu dengan menghitung nilai optimasi berikut:

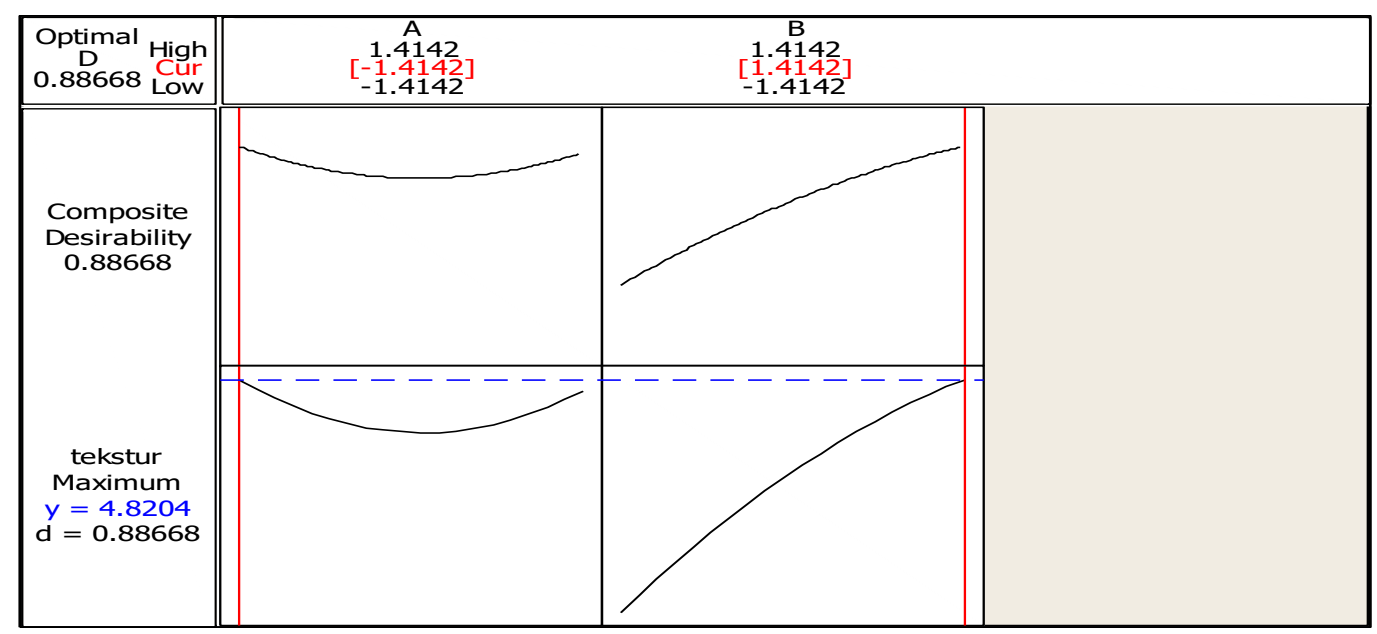

Gambar 11. Nilai Optimasi dari Parameter Tekstur.

Dari gambar 11. bahwa nilai optimasi dari tekstur akan optimal pada nilai 4.8204, dimana garis tersebut akan membentuk suatu parabola yang terbuka ke bawah yang mencirikan bahwa nilai respon aroma mempunyai nilai optimal. Kemudian, penentuan perhitungan berikut:

\section{UJI ORGANOLEPTIK FORMULASI FORTIFIKASI BEKATUL DALAM PEMBUATAN BUBUR INSTAN BERAS PANDANWANGI}

RIZA TRIHADITIA DE TRISNI KHOERUNNISA PUSPITASARI 


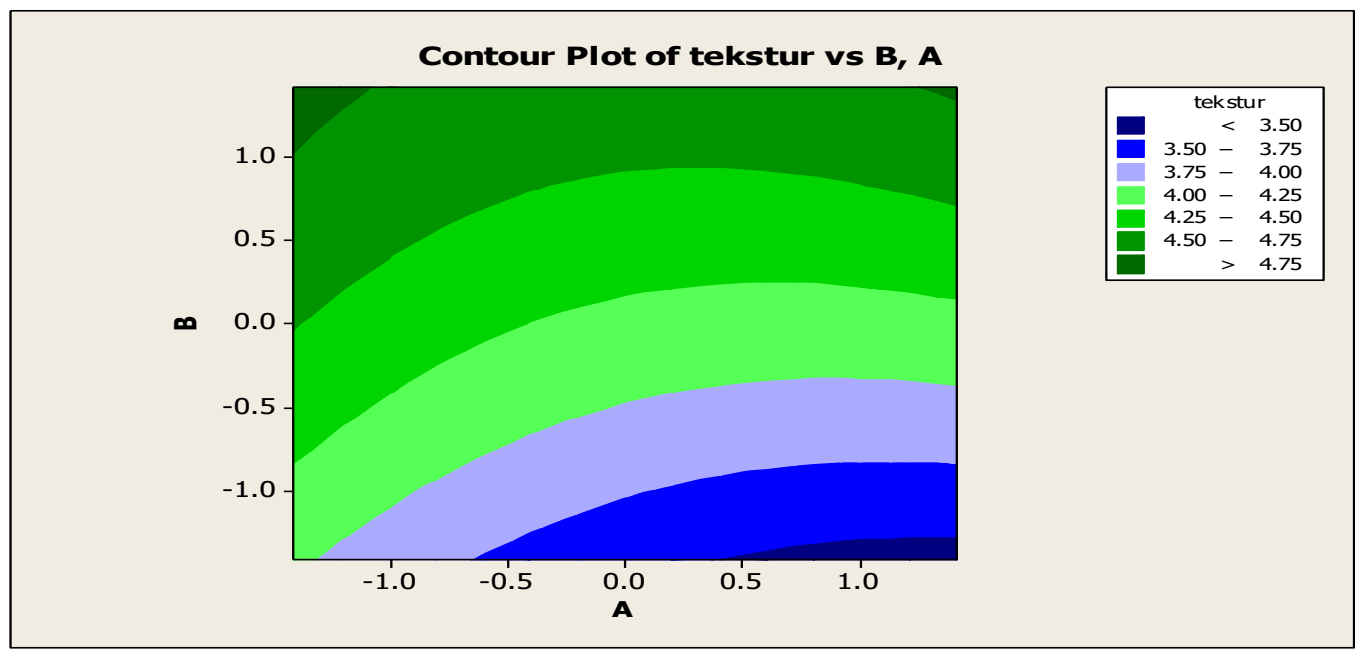

Gambar 12. Grafik Contour Plot Wilayah Optimasi dari Tekstur.

Berdasarkan gambar 12. menggambarkan bagaimana kombinasi antar komponen saling mempengaruhi nilai respon untuk parameter tekstur pada bubur instan beras Pandanwangi dengan fortifikasi bekatul. Warna-warna yang berbeda pada grafik tersebut menunjukan nilai respon dari tekstur masing-masing formula. Bentuk permukaan dari hubungan interaksi antarkomponen tersebut dapat dilihat secara jelas pada grafik tiga dimensi yaitu pada grafik surface wilayah optimasi yang ditunjukan pada gambar 13 .

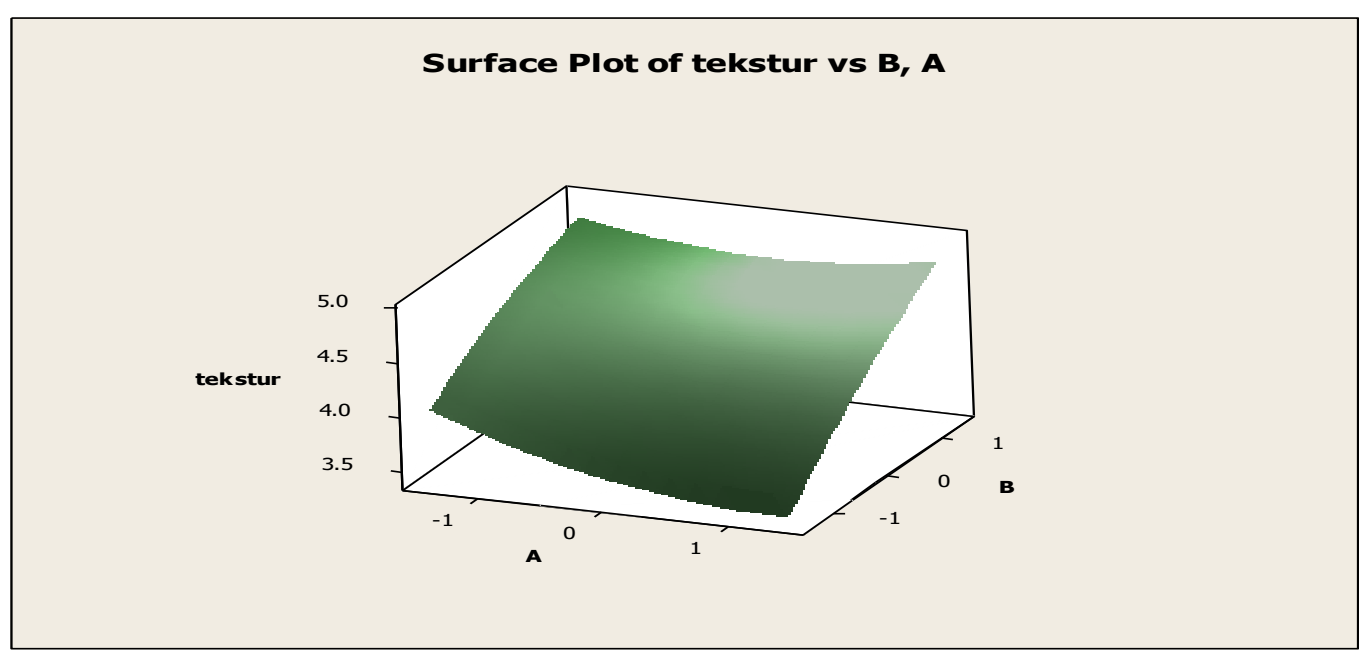

Gambar 13. Grafik Surface Wilayah Optimasi Tekstur.

Dari gambar-gambar tersebut dapat diketahui batas-batas atau penentuan wilayah optimasi. Batasan wilayah untuk nilai optimasi tekstur adalah antara 3.50 - 4.75, sehingga didapatkan penentuan wilayah optimasi berdasarkan nilai rata-rata sampel berikut:

\section{UJI ORGANOLEPTIK FORMULASI \\ FORTIFIKASI BEKATUL DALAM PEMBUATAN BUBUR INSTAN BERAS PANDANWANGI}

RIZA TRIHADITIA DE TRISNI KHOERUNNISA PUSPITASARI 
Tabel 5. Wilayah Optimasi Rata-rata Tekstur.

\begin{tabular}{cc}
\hline Wilayah Optimasi & Rata-rata Tekstur \\
\hline 1 & $>4.75$ \\
2 & $4.50-4.75$ \\
3 & $4.25-4.50$ \\
4 & $4.00-4.25$ \\
5 & $3.75-4.00$ \\
6 & $3.50-3.75$ \\
7 & $<3.50$ \\
\hline
\end{tabular}

Sumber : Data primer (olahan) tahun 2019.

Untuk memperoleh nilai optimal dari berbagai jenis sampel yang digunakan, maka nilai rata-rata dari setiap sampel dimasukkan ke dalam plot wilayah

Tabel 6. Nilai Optimasi Rata-rata Tekstur.

\begin{tabular}{ccc}
\hline Sampel & Rata-rata & Wilayah Optimasi \\
\hline F1 (PW 100\%: BK 10\%) & 3.71 & 2 \\
F2 (PW 100\%: BK 20\%) & 3.65 & 6 \\
F3 (PW 100\%: BK 30\%) & 4.19 & 4 \\
F4 (PW 100\%: BK 40\%) & 4.42 & 3 \\
F5 (PW 100\%: BK 50\%) & 4.97 & 1 \\
\hline
\end{tabular}

Sumber: Data primer (olahan) tahun 2019.

*Keterangan : PW (beras Pandanwangi) BK (Bekatul).

Berdasarkan tabel 6. dapat dikatakan bahwa sampel terbaik dari optimasi tekstur adalah sampel F5 (PW 100\% : BK 50\%), karena sampel tersebut memiliki nilai optimasi 1 yang nilai ratarata sampel berada di wilayah dengan nilai optimasi 1. Sampel yang paling disukai panelis merupakan bubur instan yang memiliki tambahan fortifikasi bekatul paling banyak, sehingga perpaduan antara beras Pandanwangi yang pulen dan bekatul yang banyak lebih dinikmati oleh panelis.

Menurut Menteri Pertanian (2004), beras Pandanwangi memiliki kadar amilosa yaitu $24.96 \%$. Berdasarkan kandungan amilosanya beras atau nasi dapat dibagi menjadi 4 golongan, yaitu: (1) beras atau nasi dengan kadar amilosa tinggi (25-33\%); (2) beras dengan kadar amilosa sedang (20-25\%); (3) beras dengan kadar amilosa rendah (9-20\%); dan (4) beras dengan kadar amilosa sangat rendah $(<9 \%)$ (Winarno, 1997 dalam Arkanti, 2007). optimasi, sehingga dihasilkan nilai optimasi dari setiap sampel tersebut yang dapat diihat pada tabel 6 .

$$
\begin{aligned}
& 4.25-4.50 \\
& 4.00-4.25 \\
& 3.75-4.00 \\
& 3.50-3.75
\end{aligned}
$$


memerangkap air serta adanya kandungan polisakarida (selulosa, hemiselulosa dan pati) dalam bahan pangan nabati yang berfungsi sebagai penguat tekstur (Irtandi, 2019).

Secara umum, setiap manusia memiliki kesukaan yang berbeda terhadap tekstur pada makanan. Ada yang menyukai makanan dengan tekstur pulen, kasar, maupun diantara keduanya yaitu tidak pulen dan tidak kasar. Pada bubur beras instan dengan fortifikasi bekatul maka terjadi kombinasi antara pulen dan kasar, diduga dengan kombinasi tersebut akan menimbulkan tekstur bubur yang khas yaitu terdapat tekstur keduanya dalam bubur. Sehingga dapat menciptakan semacam tantangan atau variasi baru pada saat mengkonsumsi bubur tersebut yang menyebabkan panelis lebih menyukai formula bubur beras instan yang memiliki fortifikasi bekatul paling banyak yaitu $50 \%$ bekatul. Selain itu, tekstur bubur instan ini dapat dipengaruhi oleh bahan dasar, ketebalan cetakan dan suhu oven yang terlalu tinggi. Selain itu pada bubur instan yang ditambahkan bekatul juga memiliki kandungan protein dan serat yang cukup tinggi dan berpengaruh pada tekstur bubur beras instan (Wulandari dan Handarsari, 2010).

Menurut Susanto (2011) juga menyatakan bahwa kadar lemak menentukan tekstur dan citarasa, sehingga dengan kadar lemak yang rendah maka penerimaan dari segi tekstur juga rendah. Kenyataan yang ada adalah memang berhubungan antara kadar lemak dengan daya terima dari segi tekstur pada bubur beras instan. Namun, penilaian secara hedonik cukup subyektif karena panelis yang satu dengan yang lainnya memiliki kesukaan masing-masing.

\section{Rasa}

Rasa merupakan faktor yang paling penting dari suatu makanan, disamping warna, aroma dan tekstur yang bagus tetapi rasa makanan tersebut tidak enak maka makanan tersebut tidak dapat dikatakan menarik bagi panelis. Rasa suatu bahan pangan dapat berasal dari sifat bahan itu sendiri atau karena adanya zat lain yang ditambahkan pada proses pengolahannya. Umumnya bahan pangan tidak hanya terdiri dari salah satu rasa, tetapi merupakan cita rasa yang utuh (Apriyantono, 2000).

Berdasarkan uji organoleptik terhadap rasa pada bubur instan beras Pandanwangi dapat dibuat Design Penelitian untuk parameter rasa, selanjutnya dilakukan perhitungan Central Composite Design sehingga didapatkan hasil grafik pada gambar 14.

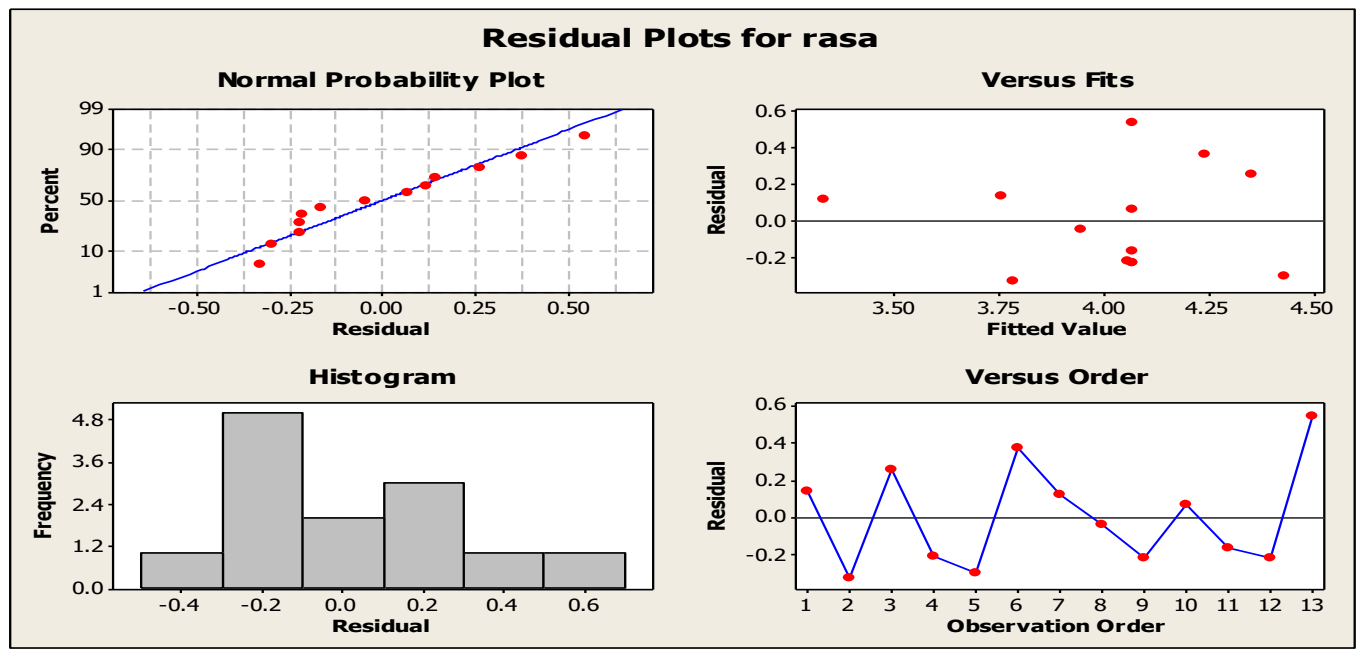

Gambar 14. Grafik Perhitungan ANOVA dari Parameter Rasa.

\section{UJI ORGANOLEPTIK FORMULASI FORTIFIKASI BEKATUL DALAM PEMBUATAN BUBUR INSTAN BERAS PANDANWANGI}

RIZA TRIHADITIA DE TRISNI KHOERUNNISA PUSPITASARI 
Dilihat dari gambar 14. bahwa titik-titik data menyebar dekat dengan garis normal dan sebagian titik-titik data berada disepanjang garis normal probability, sehingga dapat dikatakan bahwa data untuk respon rasa menyebar normal atau merata yang berarti data tersebut dikatakan baik. Data yang menyebar normal menunjukan adanya pemenuhan model terhadap asumsi ANOVA pada respon rasa, sehingga dapat dilakukan perhitungan selanjutnya yaitu dengan menghitung nilai optimasi berikut:

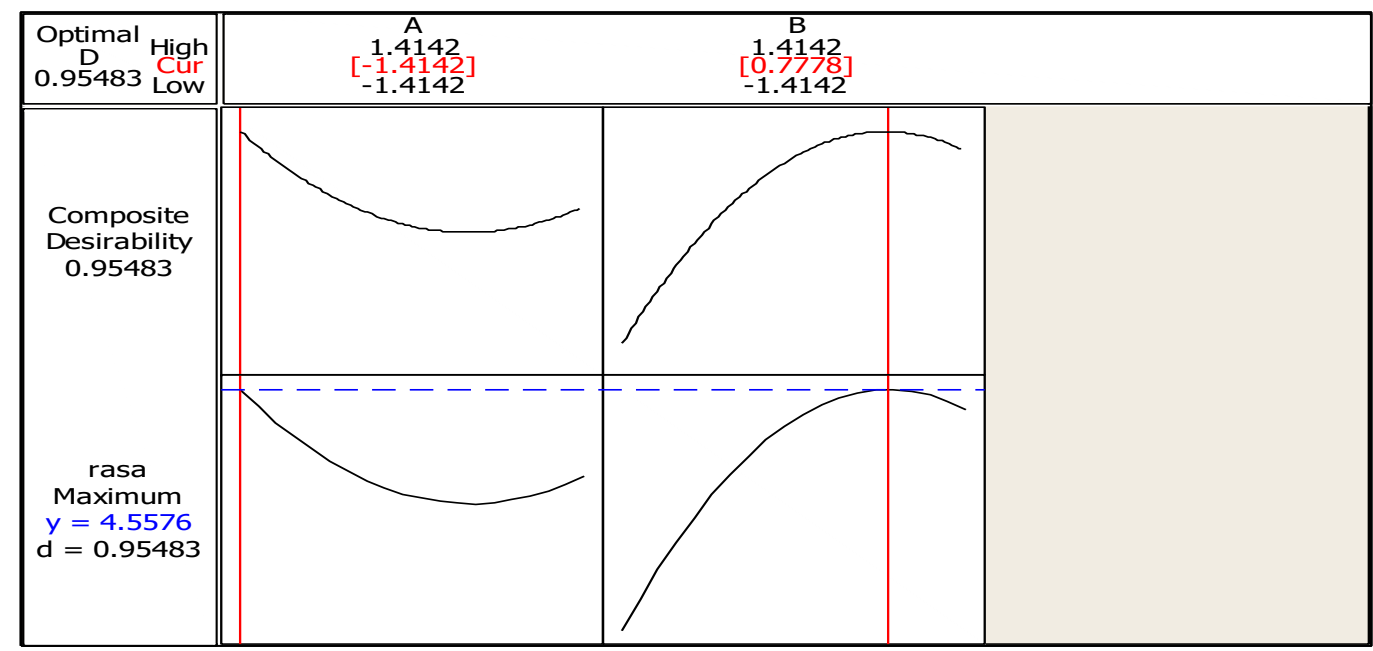

Gambar 15. Nilai Optimasi Dari Parameter Rasa.

Pada gambar 15. bahwa nilai optimasi dari rasa akan optimal pada nilai 4.5576, dimana garis tersebut akan membentuk suatu parabola yang terbuka ke bawah yang mencirikan bahwa nilai respon rasa mempunyai nilai optimal. Kemudian, penentuan daerah optimasi digunakan grafik secara contour dan surface, maka akan dihasilkan perhitungan berikut:

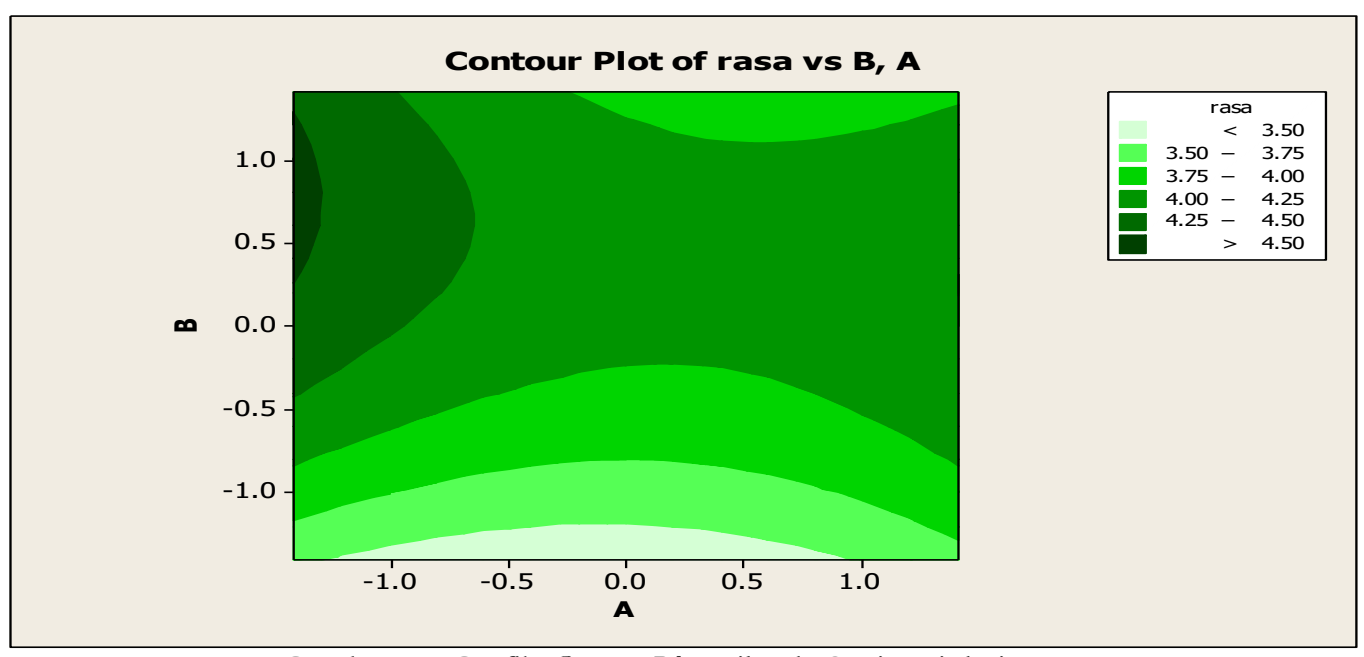

Gambar 16. Grafik Contour Plot Wilayah Optimasi dari Rasa.

Berdasarkan grafik contour plot pada gambar 16. menggambarkan bagaimana kombinasi antar komponen saling mempengaruhi nilai respon untuk parameter rasa pada bubur instan beras Pandanwangi dengan fortifikasi bekatul.

\section{UJI ORGANOLEPTIK FORMULASI FORTIFIKASI BEKATUL DALAM PEMBUATAN BUBUR INSTAN BERAS PANDANWANGI}

RIZA TRIHADITIA DE TRISNI KHOERUNNISA PUSPITASARI 
Warna-warna yang berbeda pada grafik tersebut menunjukan nilai respon dari rasa masing-masing formula. Bentuk permukaan dari hubungan interaksi antar komponen tersebut dapat dilihat secara jelas pada grafik tiga dimensi yaitu pada grafik surface wilayah optimasi yang ditunjukan pada gambar 17.

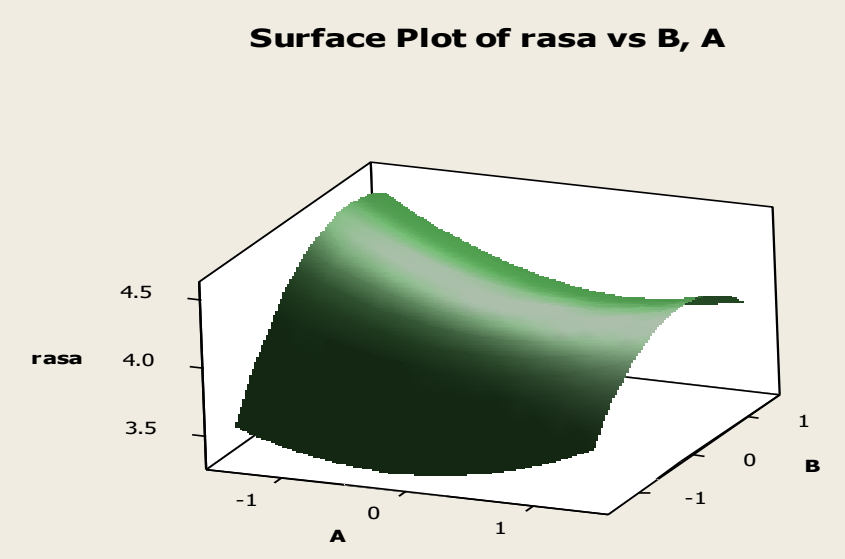

Gambar 17. Grafik Surface Wilayah Optimasi Rasa.

Pada gambar 16. dapat diketahui batas-batas atau penentuan wilayah optimasi. Batasan wilayah untuk nilai optimasi rasa adalah antara $3.50-4.50$,

Tabel 7. Wilayah Optimasi Rata-rata Rasa.

\begin{tabular}{cc}
\hline Wilayah Optimasi & Rata-rata Rasa \\
\hline 1 & $>4.50$ \\
2 & $4.25-4.50$ \\
3 & $4.00-4.25$ \\
4 & $3.75-4.00$ \\
5 & $3.50-3.75$ \\
6 & $<3.50$ \\
\hline
\end{tabular}

Sumber : Data primer (olahan) tahun 2019.

Untuk memperoleh nilai optimal dari berbagai jenis sampel yang digunakan, maka nilai rata-rata dari setiap sampel dimasukkan ke dalam plot wilayah

sehingga didapatkan penentuan wilayah optimasi berdasarkan nilai rata-rata sampel pada tabel 7 .

optimasi, sehingga dihasilkan nilai optimasi dari setiap sampel tersebut yang dapat diihat pada tabel 8 .

Tabel 8. Nilai Optimasi Rata-rata Rasa.

\begin{tabular}{ccc}
\hline Sampel & Rata-rata & Wilayah Optimasi \\
\hline F1 (PW 100\%: BK 10\%) & 3.90 & 4 \\
F2 (PW 100\%: BK 20\%) & 3.45 & 6 \\
F3 (PW 100\%: BK 30\%) & 4.61 & 1 \\
F4 (PW 100\%: BK 40\%) & 3.84 & 4 \\
F5 (PW 100\%: BK 50\%) & 4.13 & 3 \\
\hline
\end{tabular}

Sumber: Data primer (olahan) tahun 2019.

*Keterangan : PW (beras Pandanwangi) BK (Bekatul).

\section{UJI ORGANOLEPTIK FORMULASI \\ FORTIFIKASI BEKATUL DALAM PEMBUATAN BUBUR INSTAN \\ BERAS PANDANWANGI}

RIZA TRIHADITIA DE TRISNI KHOERUNNISA PUSPITASARI 
Berdasarkan tabel 8. dapat dikatakan bahwa sampel terbaik dari optimasi rasa adalah sampel dengan F3 (PW 100\% : BK 30\%) yang memiliki nilai optimasi 1, dikarenakan nilai rata-rata sampel tersebut berada di wilayah tertinggi yaitu 1 . Hal ini diduga bahwa panelis lebih menyukai bubur instan beras Pandanwangi yang memiliki fortifikasi bekatul dengan presentase sedang (moderat) tidak terlalu banyak dan tidak terlalu sedikit bekatul. Menurut sebagian panelis memberikan penilaian bahwa rasa dari bubur instan yang diberi fortifikasi bekatul memiliki rasa yang agak pahit (sepat). Rasa pahit pada bubur yang diberi bekatul diduga dikaitkan dengan kandungan tanin yang terkandung dalam bekatul. Menurut Mithania (2017) dalam penelitiannya menunjukkan bahwa fraksi air pada bekatul mengandung tanin sebesar 48,96 ppm. Senyawa tanin merupakan senyawa astringent yang memiliki rasa pahit dari gugus polifenolnya yang dapat mengikat dan mengendapkan atau menyusutkan protein (Ismarani, 2012).

Menurut Hadi dan Siratunnisak (2016), bekatul memiliki karakteristik yang khas pada rasanya yang pahit, ini berkaitan dengan kandungan saponin pada bekatul. Namun, rasa pahit yang berlebihan diduga berhubungan dengan proses kerusakan lipid dan protein. Oksidasi fosfatidilkolin, asam amino, dan peptida diketahui menimbulkan rasa pahit. Hal ini disebabkan, karena proses pengovenan atau pemanasan bekatul diduga mampu meningkatkan reaksi Maillard, yang penting sebagai sumber cita rasa. Sebenarnya, Bekatul memiliki rasa manis yang disebabkan oleh adanya kandungan gula bekatul dan lembaga yang relatif tinggi. Sedangkan rasa khas bekatul muncul disebabkan oleh kandungan minyak dari bekatul itu sendiri (tokol, tokoferol, tokotrienol) (Sarbini et al., 2009).

\section{E. Penentuan Sampel Terbaik}

Penentuan sampel terbaik didapatkan berdasarkan nilai optimasi yang diperoleh dari setiap parameter yaitu warna, aroma, tekstur, dan rasa bubur instan beras Pandanwangi dengan fortifikasi bekatul. Dari hasil tersebut dapat menentukan satu sampel terbaik berdasarkan uji organoleptik dari setiap parameter yang diuji. Penentuan sampel terbaik dapat dilihat pada tabel 9.

Tabel 9. Penentuan sampel terbaik.

\begin{tabular}{ccccccccc}
\hline \multirow{2}{*}{$\begin{array}{c}\text { Sam } \\
\text { pel }\end{array}$} & \multicolumn{2}{c}{ Warna } & \multicolumn{2}{c}{ Aroma } & \multicolumn{2}{c}{ Tekstur } & \multicolumn{2}{c}{ Rasa } \\
\cline { 2 - 9 } & $\begin{array}{c}\text { Rata- } \\
\text { rata }\end{array}$ & Optimasi & $\begin{array}{c}\text { Rata- } \\
\text { rata }\end{array}$ & Optimasi & $\begin{array}{c}\text { Rata- } \\
\text { rata }\end{array}$ & Optimasi & $\begin{array}{c}\text { Rata- } \\
\text { rata }\end{array}$ & Optimasi \\
\hline F1 & 4.13 & 1 & 4.84 & 3 & 3.71 & 2 & 3.9 & 4 \\
F2 & 3.71 & 3 & 4.45 & 7 & 3.65 & 6 & 3.45 & 6 \\
F3 & 3.58 & 5 & 4.94 & 2 & 4.19 & 4 & 4.61 & 1 \\
F4 & 3.45 & 6 & 4.48 & 7 & 4.42 & 3 & 3.84 & 4 \\
F5 & 3.74 & 3 & 4.87 & 3 & 4.97 & 1 & 4.13 & 3 \\
\hline
\end{tabular}

Sumber : Data primer (olahan) tahun 2019.

*Keteranga :

F1 = beras Pandanwangi 100\% + Bekatul 10\%

F2 $=$ beras Pandanwangi 100\% + Bekatul 20\%

F3 = beras Pandanwangi 100\% + Bekatul 30\%

F4 = beras Pandanwangi 100\% + Bekatul 40\%

F5 = beras Pandanwangi 100\% + Bekatul 50\%

\section{UJI ORGANOLEPTIK FORMULASI \\ FORTIFIKASI BEKATUL DALAM PEMBUATAN BUBUR INSTAN BERAS PANDANWANGI}

RIZA TRIHADITIA DE TRISNI KHOERUNNISA PUSPITASARI 
Pada tabel 9. menunjukan bahwa terdapat nilai optimasi dengan karakteristik setiap parameter uji organoleptik yang berbeda dari setiap sampel. Dari nilai optimasi tersebut menunjukan kelas pada nilai parameter organoleptik tersebut, dimana semakin kecil nilai optimasi maka semakin tinggi nilai kelas yang diperoleh. Sebaliknya, semakin besar nilai optimasi yang diperoleh, maka nilai kelas akan semakin rendah. Oleh karena itu, sampel yang memiliki nilai optimasi kecil menunjukan bahwa sampel tersebut lebih disukai panelis. Sedangkan, sampel yang memiliki nilai optimasi tinggi menunjukan bahwa sampel tersebut kurang disukai oleh panelis.

Tabel 9. juga menunjukan bahwa dari setiap sampel memiliki keunggulan atau nilai optimasi paling tinggi dari setiap parameter, sehingga tidak ada sampel yang paling dominan dari semua parameter baik warna, aroma, tekstur, maupun rasa. Namun, jika dilihat dari keseluruhan parameter tersebut, nilai sampel F5 (beras Pandanwangi 100\%: Bekatul 50\%) dapat dikatakan mendapatkan nilai optimasi tertinggi diantara sampel yang lain baik dari segi warna, aroma, tekstur, dan rasa, dikarenakan pada sampel F5 (beras Pandanwangi 100\%: Bekatul 50\%) menunjukan bahwa nilai otimasinya stabil meskipun nilai optimasi yang diperoleh sampel tersebut tidak berada di wilayah tertinggi namun sampel tersebut tidak berada di wilayah paling rendah sehingga dapat dikatakan bahwa sampel terbaik yang disukai panelis merupakan sampel F5 (beras Pandanwangi 100\%: Bekatul $50 \%$ ).

Sedangkan, tingkat kesukaan panelis yang paling minimum terhadap parameter warna, aroma, tekstur, dan rasa dari bubur instan beras Pandanwangi dengan fortifikasi bekatul adalah pada sampel F2 = beras Pandanwangi 100\%: Bekatul 20\%, dikarenakan nilai optimasi yang diperoleh dari setiap parameter selalu rendah.

\section{KESIMPULAN}

Pembuatan bubur instan beras Pandanwangi dengan fortifikasi bekatul memiliki pengaruh terhadap mutu organoleptik seperti warna, aroma, tekstur, dan rasa. Dari keseluruhan parameter mutu organoleptik, yang paling diminati oleh panelis adalah sampel F5 (beras Pandanwangi 100\%: Bekatul 50\%) dengan nilai optimasi warna yaitu 3 , nilai optimasi aroma 3, nilai optimasi tekstur 1, dan nilai optimasi rasa yaitu 3 .

\section{DAFTAR PUSTAKA}

Anonim (2005). Pedoman Umum Pengadaan Gabah dan Beras dalam Negeri Tabun 2005 di Lingkungan Perusahaan Umum BULOG. Divisi Pengadaan Perum BULOG, Jakarta.

Apriyantono, 2000. Analisis Kimia. Institut Pertanian Bogor Press. Bogor.

Aritonang, A.L.P. 2014. Analisis Metode Response Surface Pada Produksi Biodiesel Secara Katalitik Dengan Static Mixing Reactor. Skripsi. Institut Pertanian Bogor. Bogor.

Astawan, M. dan A.E. Febrinda. 2010. Potensi Dedak dan Bekatul Beras sebagai Ingredient Pangan dan Produk Pangan Funsional. Pangan. 19(1).

Astawan, M. dan A. Leomitro. 2009. Khasiat Whole Grain: Makanan Kaya Serat untuk Hidup Sehat. Gramedia Pustaka Utama. Jakarta.

Arkanti, L.W. 2007. Karakterisasi Sifat Fisiko-Kimia dan Sensori Beras Pandanwangi, Morneng, dan BTN. Skripsi. Institut Pertanian Bogor. Bogor.

$\begin{array}{lrr}\text { UJI ORGANOLEPTIK } & \text { FORMULASI } & \text { RIZA TRIHADITIA } \\ \text { FORTIFIKASI B BEKATUL } & \text { DALAM } & \text { DE TRISNI KHOERUNNISA PUSPITASARI } \\ \text { PEMBUATAN BUBUR INSTAN } & & \\ \text { BERAS PANDANWANGI } & & \end{array}$


BPOM (Badan Pengawas Obat dan Makanan). 2005. Peraturan Kepala Badan Pengawas Obat Dan Makanan Republikin Donesia Nomor He 00.0s.52.0685 Tentang Ketentuan Pokok Pengawasan Pangan Fungsional. Kepala Badan Pengawas Obat Dan Makanan Ri. Jakarta.

Hadi, A. dan N. Siratunnisak. 2016. Pengaruh Penambahan Bubuk Coklat Terhadap Sifat Fisik, Kimia, dan Organoleptik Minuman Instan Bekatul. Jurnal Action. Aceh Nutritional Journal. 1 (2): $121-129$.

Handayani, Y. 2016. Olahan Cake dengan Fortifikasi Sayuran Bayam. Balai Pengkajian Teknologi Pertanian (BPTB). Jakarta.

Irtandi, L.L. 2019. Korelasi Konsentrasi Daging Sapi Dan Konsentrasi Bekatul Terhadap Karakterisik Sosis. Tugas Akhir. Program Studi Teknologi Pangan Fakultas Teknik Universitas Pasundan. Bandung.

Ismarani. 2012. Potensi Senyawa Tannin Dalam Menunjang Produksi Ramah Lingkungan. Jurnal Agribisnis dan Pengembangan Wilayah. 3 (2).

Menteri Pertanian. 2004. Keputusan Menteri Pertanian Nomor : 163/Kpts/LB.240/3/2004

Pelepasan Galur Padi Sawah Lokal Pandanwangi Cianjur Sebagai Varietas Unggul Dengan Nama Pandanwangi. Menteri Pertanian. Jakarta.

Luthfianto, D. , R.D. Noviyanti, I. Kurniawati. 2017. Karakterisasi Kandungan Zat Gizi Bekatul pada Berbagai Varietas Beras di Surakarta. The 6th University Research Colloquium 2017 Universitas Muhammadiyah Magelang, ISSN 2407-9189.
Mithania, D. 2017. Produk Agar-agar dengan Penambahan Bekatuldan Angkak sebagai Alternatif Cemilan Penurun Kolestrol. Departemen Ilmu Dan Teknologi Pangan Fakultas Teknologi Pertanian. Skripsi. Institute Pertanian Bogor. Bogor.

MP3C (Masyarakat Pelestari Padi Pandawangi Cianjur). 2015. Buku Persyaratan Indikasi Geografis Beras Pandanwangi Cianjur. Cianjur.

Nurjaya dan Maulida, N. 2018. Tingkat Kesukaan Konsumen pada Atribut Beras Pandanwangi Murni Cianjur. Agroscience. 8(1).

Sarbini, D., S. Rahmawaty, dan P. Kurnia. 2009. Uji Fisik, Organoleptik, Dan Kandungan Zat Gizi Biskuit Tempe-Bekatul Dengan Fortifikasi Fe Dan Zn Untuk Anak Kurang Gizi. Jurnal Penelitian Sains \& Teknologi. 10 (1): $18-26$.

Susanto, D. 2011. Potensi Bekatul Sebagai Sumber Antioksidan Dalam Produk Selai Kacang. Artikel Penelitian. Program Studi Ilmu Gizi Fakultas Kedokteran Universitas Diponegoro. Semarang.

Tetelepta, G. dan P. Picauly. 2015. Uji Organoleptik Bubur Instan Berbahan Dasar Tepung Pisang Tongka Langit. AGRITEKNO, Jurnal Teknologi Pertanian. 4(2).

Trihaditia, R. 2015. Penentuan Formulasi Optimum pada Pembuatan Minuman Fungsional Rambut Jagung dengan Penambahan Madu dan Jeruk Nipis Menggunakan Metode RSM (Response Surface Method). Tesis. Fakultas Teknologi Pangan Universitas Pasundan. Bandung.

Tuarita, M.Z., N.F. Sadek, Sukarno, N.D. Yuliana, dan S. Budijanto. 2017. Pengembangan Bekatul sebagai Pangan Fungsional: Peluang,

$\begin{array}{lrr}\text { UJI ORGANOLEPTIK } & \text { FORMULASI } & \text { RIZA TRIHADITIA } \\ \text { FORTIFIKASI BEKATUL } & \text { DALAM } & \text { DE TRISNI KHOERUNNISA PUSPITASARI } \\ \text { PEMBUATAN BUBUR INSTAN } & & \\ \text { BERAS PANDANWANGI } & & \end{array}$


Hambatan, dan Tantangan. Jurnal Pangan.

Wariyah, C. 2010. Restrukturisasi Menir Menjadi Beras Berkalsium Tinggi Dengan Metode Ekstrusi. AGRITECH. 30 (3).

Wijaya, H., Kusbiantoro, B., Faridah, D.N., Handoko, D.D., Taufik. 2008. Identifikasi Komponen Aroma Aktif Beberapa Varietas

Beras (Oryza miristica L.) Aromatik Asli Indonesia sebagai Upaya Pemanfaatan Potensi Beras Indonesia. Ringkasan Penelitian. Jakarta (ID): Badan Litbang Pertanian.

Winarno, F.G. 2004. Kimia Pangan dan Gizi. PT. Gramedia Pustaka Utama, Jakarta.

Wulandari, M. dan E. Handasari. 2010. Pengaruh Penambahan Bekatul Terhadap Kadar Protein dan Sifat Organoleptik Biskuit. Program DIII Gizi Fakultas Ilmu Keperawatan dan Kesehatan. Tugas Akbir. Universitas Muhammadiyah Semarang.

Yunita, O., S. Sirajuddin, U. Najamuddin. 2014. Analisis Daya Terima Bubur Bekatul Instan pada Anak Obesitas Usia Sekolah Dasar di Makassar Tahun 2014. Program Studi Ilmu Gizi Fakultas Kesehatan Masyarakat Universitas Hasanudin.

$\begin{array}{lrr}\text { UJI ORGANOLEPTIK } & \text { FORMULASI } & \text { RIZA TRIHADITIA } \\ \text { FORTIFIKASI BEKATUL } & \text { DALAM } & \text { DE TRISNI KHOERUNNISA PUSPITASARI } \\ \text { PEMBUATAN BUBUR INSTAN } & & \\ \text { BERAS PANDANWANGI } & & \end{array}$

